\title{
AS GARANTIAS BASEADAS NA PROPRIEDADE FIDUCIÁRIA NO DIREITO BRASILEIRO
}

\author{
Dissertação de Mestrado \\ Orientador: Professor Associado Dr. Claudio Luiz Bueno de Godoy
}

UNIVERSIDADE DE SÃO PAULO

FACULDADE DE DIREITO

São Paulo-SP

2020 


\section{AS GARANTIAS BASEADAS NA PROPRIEDADE FIDUCIÁRIA NO DIREITO BRASILEIRO}

Dissertação apresentada à Banca Examinadora do Programa de Pós-Graduação em Direito, da Faculdade de Direito da Universidade de São Paulo, como exigência parcial para obtenção do título de Mestre em Direito, na área de concentração de Direito Civil, sob a orientação do Professor Associado Dr. Claudio Luiz Bueno de Godoy.

UNIVERSIDADE DE SÃO PAULO

FACULDADE DE DIREITO

São Paulo-SP

2020 
Catalogação da Publicação

Serviço de Biblioteca e Documentação

Faculdade de Direito da Universidade de São Paulo

De Conti, Bruno Cezar Toledo

As garantias baseadas na propriedade fiduciária no direito brasileiro ; Bruno Cezar Toledo De Conti ; orientador, Claudio Luiz Bueno de Godoy São Paulo, 2020.

196 p. ; $30 \mathrm{~cm}$.

Dissertação (Mestrado - Programa de Pós-Graduação em Direito

Civil) - Faculdade de Direito, Universidade de São Paulo, 2020.

1. Garantia real. 2. Cessão fiduciária. 3. Alienação fiduciária. 4. Propriedade fiduciária. I. Godoy, Claudio Luiz Bueno de, oriente. II. Título. 
Nome: DE CONTI, Bruno Cezar Toledo

Título: As garantias baseadas na propriedade fiduciária no direito brasileiro

Dissertação apresentada à Banca Examinadora do Programa de Pós-Graduação em Direito, da Faculdade de Direito da Universidade de São Paulo, como exigência parcial para obtenção do título de Mestre em Direito, na área de concentração de Direito Civil.

Aprovado em:

Banca Examinadora

Prof. Dr.

Instituição:

Julgamento:

Prof. Dr.

Instituição:

Julgamento:

Prof. Dr.

Instituição:

Julgamento: 
Aos meus pais, Julio e Elaine, por tornarem tudo possível. 


\section{AGRADECIMENTOS}

Agradeço ao meu orientador, Dr. Claudio Luiz Bueno de Godoy, excepcional jurista e professor, com quem tive o prazer de aprender Direito Civil desde a minha graduação, pela oportunidade e pela orientação cuidadosa, fundamental para os méritos que essa dissertação possa ter.

Agradeço à minha querida Giordana, pelo carinho, por todo o companheirismo, pelo apoio irrestrito, pelos inúmeros conselhos, pelas palavras de conforto e pela enorme paciência.

Agradeço aos meus pais, pelo amor e carinho, e por propiciarem todas as condições, materiais e imateriais, para que eu pudesse chegar até aqui.

Agradeço ao meu irmão, Caio, à toda minha família e aos meus amigos pela presença e parceria de sempre.

Agradeço à equipe RFT, melhor time que alguém poderia querer, e especialmente ao meu chefe e amigo Renan, pelo apoio, pela compreensão e pelos conselhos. 


\section{RESUMO}

DE CONTI, Bruno Cezar Toledo. As garantias baseadas na propriedade fiduciária no direito brasileiro. 2020. 196 f. Dissertação (Mestrado em Direito Civil) - Faculdade de Direito, Universidade de São Paulo, São Paulo, 2020.

O objetivo desta dissertação é identificar os pontos comuns entre todas as garantias que se utilizam da propriedade fiduciária no direito brasileiro, considerando que o legislador não sistematizou os diversos tipos de contrato de alienação fiduciária e de cessão fiduciária tipificados, gerando situações de insegurança jurídica. Para se chegar às garantias fiduciárias, nome didaticamente dado à categoria comum que abrange todas as espécies de garantias baseadas na propriedade fiduciária, iniciou-se o estudo pela análise dos institutos que inspiraram a criação dessas garantias. Em seguida, observou-se a evolução legislativa brasileira envolvendo as garantias fiduciárias ao longo dos mais de 50 anos passados desde a criação delas para, então, se chegar às leis na forma em que postas atualmente. Com essas informações, somadas à ampla análise da doutrina e da jurisprudência, foi possível obter as características gerais das garantias fiduciárias. As características comuns foram identificadas na constituição das garantias fiduciárias, em aspectos do funcionamento delas enquanto a dívida não vence e nas consequências do inadimplemento da dívida garantida.

Palavras-chave: Garantia real. Cessão fiduciária. Alienação fiduciária. Propriedade fiduciária. 


\begin{abstract}
DE CONTI, Bruno Cezar Toledo. The guarantees based on fiduciary ownership in Brazilian Law. 2020. 196 p. Dissertation (Master in Civil Law) - Faculdade de Direito, Universidade de São Paulo, São Paulo, 2020.

The objective of this dissertation is to identify the common points among the species of security based on fiduciary ownership in Brazilian Law, considering that lawmakers did not systematize the various types of fiduciary alienation and fiduciary assignment contracts, generating situations of legal uncertainty. To address the fiduciary security, a name didactically given to the category that covers all types of security based on fiduciary ownership, the study begins by analyzing the institutes that inspired the creation of these security. Then it describes the evolution of Brazilian legislation involving these security over the nearly fifty years since their creation, and explains the various features of the laws as worded today. With this information, along with a thorough analysis of the doctrine and jurisprudence, it was possible to obtain the general characteristics of fiduciary security. These common characteristics are identified in the constitution of the security, aspects of their functioning until the maturity date of the secured debt and the consequences of default.
\end{abstract}

Keywords: In rem security. Fiduciary assignment. Fiduciary alienation. Fiduciary ownership. 


\section{SUMÁRIO}

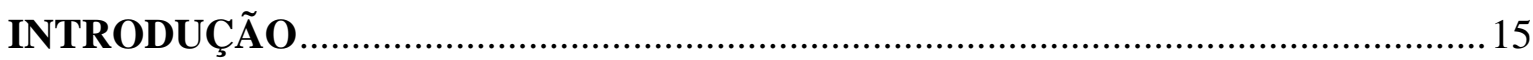

1. FONTES DE INSPIRAÇÃO DAS GARANTIAS FIDUCIÁRIAS ..........................2 25

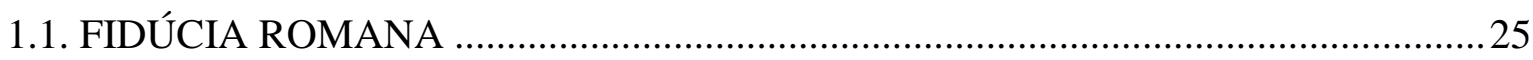

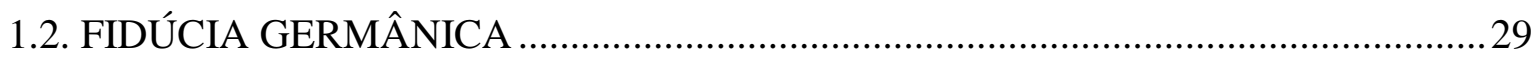

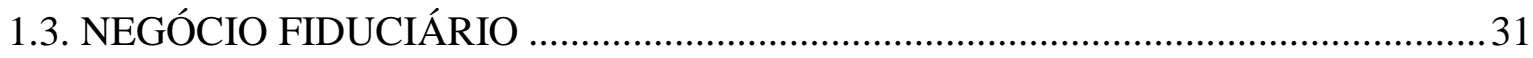

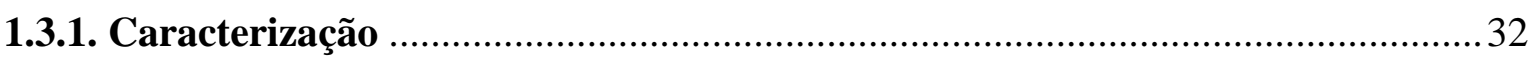

1.3.2. Figuras afins e a validade do negócio fiduciário .............................................. 41

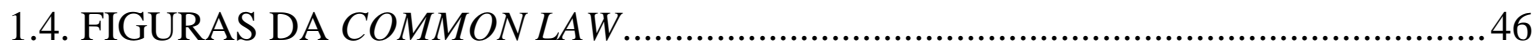

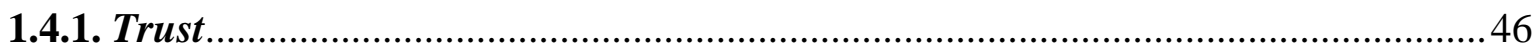

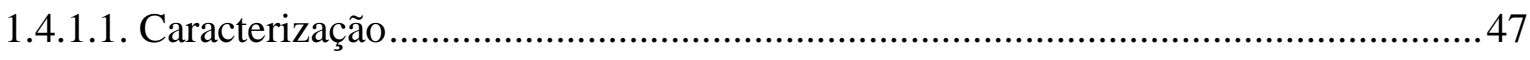

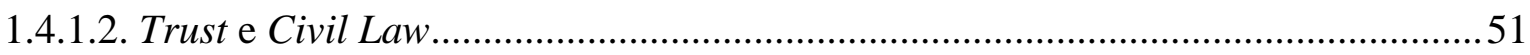

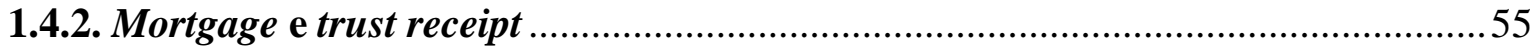

2. AS GARANTIAS FIDUCIÁRIAS NA LEGISLAÇÃO BRASILEIRA ...................59

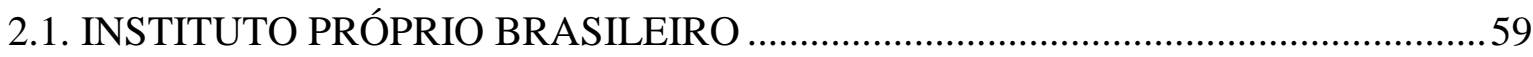

2.2. EVOLUÇÃO LEGISLATIVA DAS GARANTIAS FIDUCIÁRIAS ............................. 63

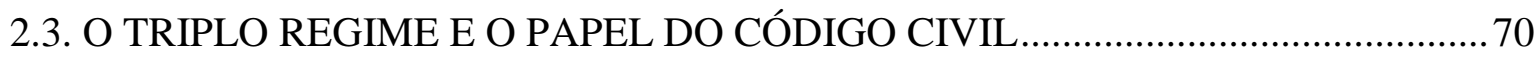

3. TEORIA GERAL DAS GARANTIAS FIDUCIÁRIAS ......................................... 73

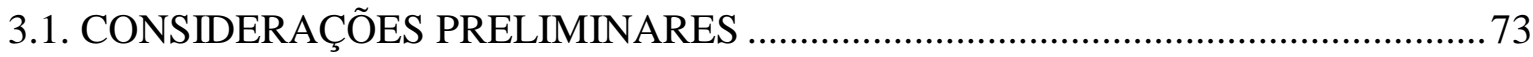

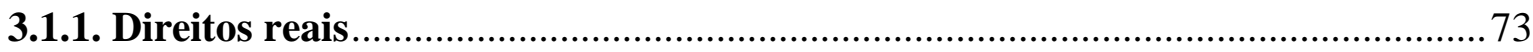

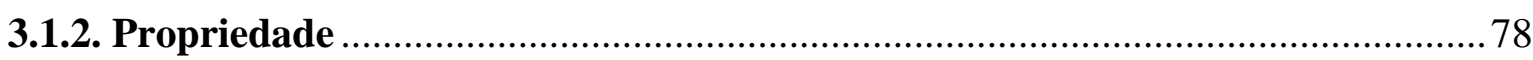

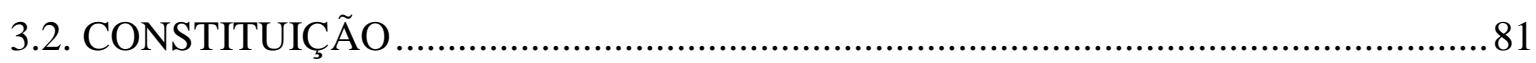

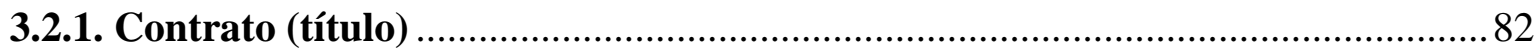

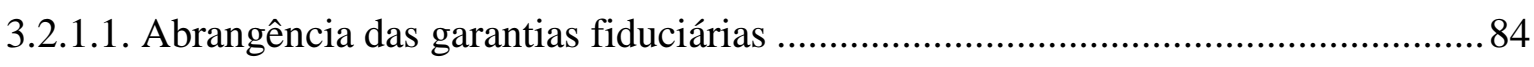

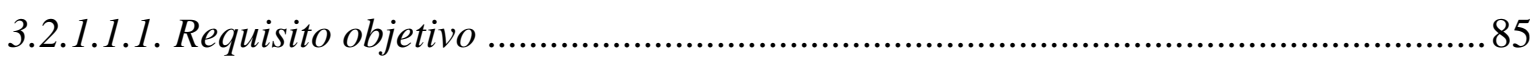

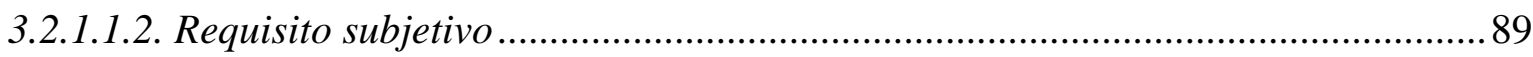

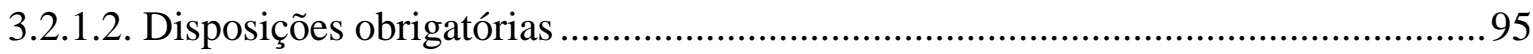

3.2.1.2.1. Aspectos da especialização nas garantias fiduciárias .........................................97

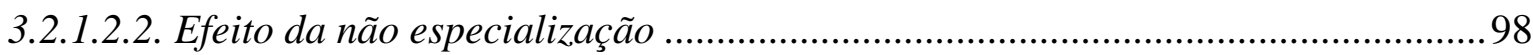

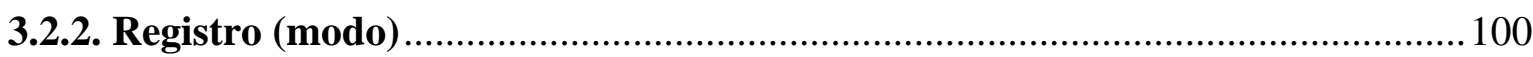

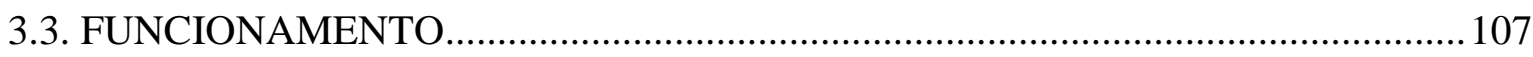

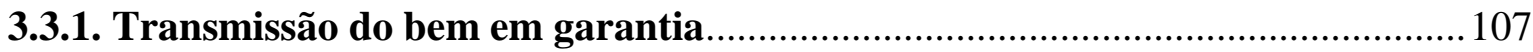


3.3.1.1. A alienação da propriedade 108

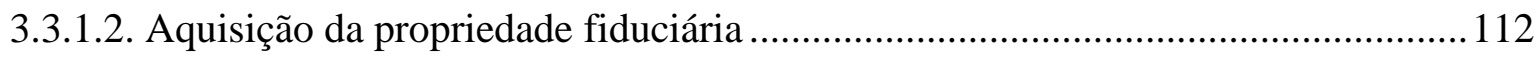

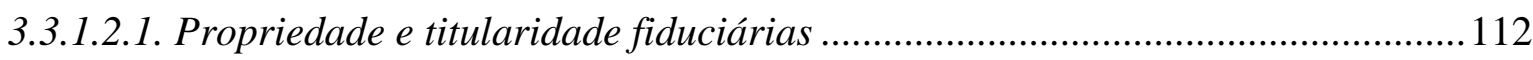

3.3.1.2.2. Conceituação da propriedade fiduciária ........................................................... 116

3.3.2. Propriedade fiduciária como propriedade resolúvel ....................................... 118

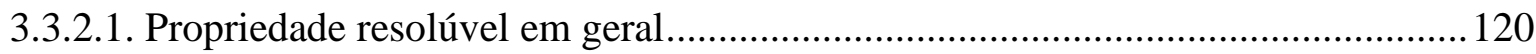

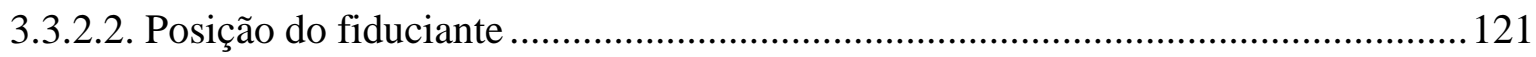

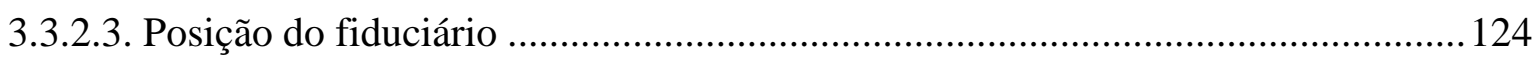

3.3.3. Propriedade fiduciária como propriedade limitada ........................................ 126

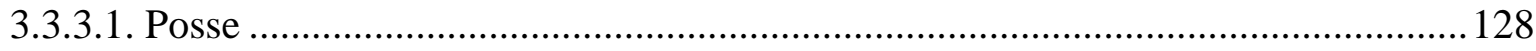

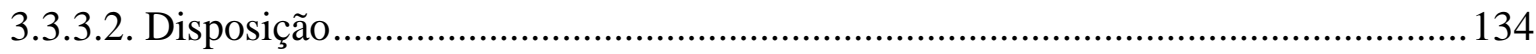

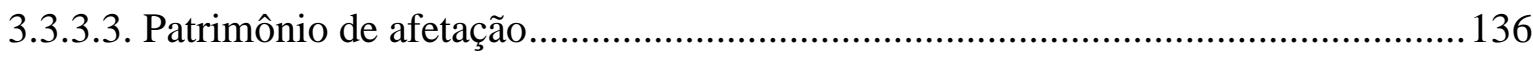

3.3.4. Propriedade fiduciária como propriedade desonerada ..................................... 140

3.3.4.1. Ausência de responsabilidade quanto às obrigações advindas do objeto da garantia

3.3.4.2. Ausência de obrigações e risco quanto ao objeto da garantia............................... 146

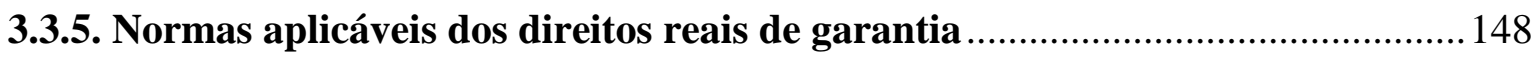

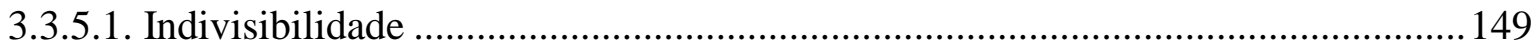

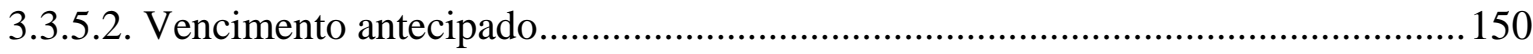

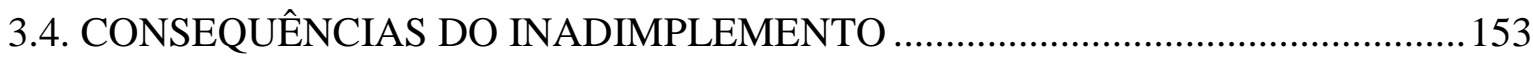

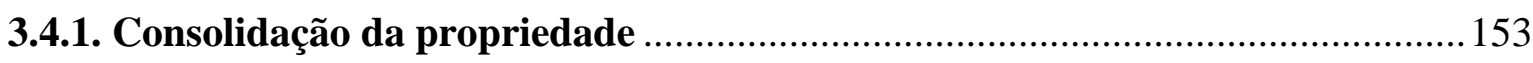

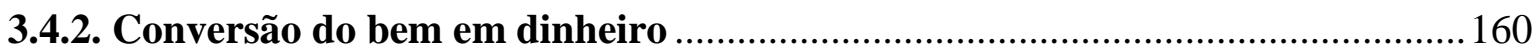

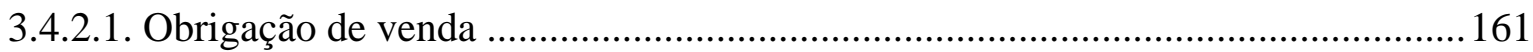

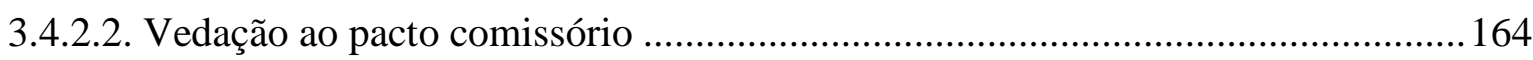

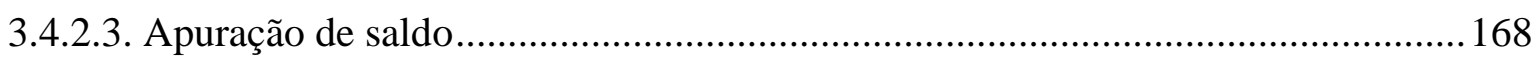

3.4.2.4. Formas lícitas de o fiduciário obter definitivamente o bem .................................. 174

3.5. PROPRIEDADE FIDUCIÁRIA COMO PROPRIEDADE ....................................... 177

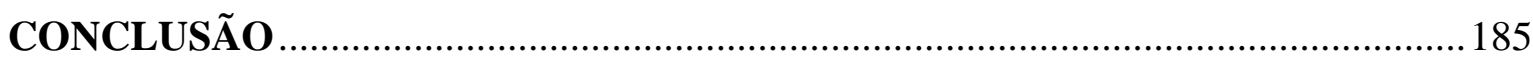

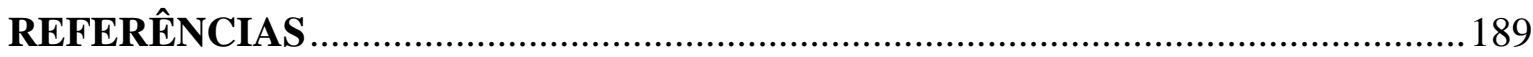




\section{INTRODUÇÃO}

O crédito ocupa posição fundamental na sociedade atual. É contando com ele que milhares de pessoas sonham com a compra de um carro e até de uma residência. É contando com ele que empresários e sociedades empresariais buscam crescer e expandir seus negócios. Em suas mais variadas formas, o crédito nada mais é do que uma das principais engrenagens do sistema capitalista, sendo diretamente responsável por fazer a economia girar. ${ }^{1}$

Consequentemente, ocupam papel central na economia aqueles que estão dispostos a emprestar, ou seja, a aplicar seu capital (ou de outros poupadores, como no caso das instituições financeiras ${ }^{2}$ ) na perseguição do objetivo de outra pessoa, na esperança de que, no futuro, o recuperarão com a remuneração que consideram adequada.

É claro que a operação de emprestar à vista para receber a prazo implica a assunção do risco de inadimplemento do devedor, o risco de crédito. ${ }^{3} \mathrm{E}$, apesar de inexistir "crédito totalmente isento de risco", esse risco deve ser reduzido ao máximo, especialmente na atividade bancária, que lida com a poupança popular. ${ }^{4}$ É necessária a usual construção de "diques, barragens, amortecedores" contra os efeitos negativos do risco. ${ }^{5}$

Ganham grande relevância, assim, os mecanismos aptos a conferir não apenas esperança ao credor, mas segurança de que o capital emprestado poderá ser recuperado da forma mais célere possível na hipótese de inadimplemento.

Tal probabilidade de recuperação, por sua vez, estará diretamente relacionada com as variadas garantias que podem ser dadas ao credor, que têm como função a cobertura

\footnotetext{
${ }^{1}$ Sobre a importância do crédito, ver: RESTIFFE, Paulo Sérgio. Garantias tradicionais no novo Código Civil. Revista dos Tribunais, São Paulo, v. 821, mar. 2004, p. 731; CHALHUB, Melhim Namem; ASSUMPÇÃO, Márcio Calil de. Cessão fiduciária de direitos creditórios: aspectos da sua natureza jurídica e seu tratamento no concurso de credores. RTDC: Revista Trimestral de Direito Civil. Rio de Janeiro, v.10, n. 38, abr./jun. 2009, p. 82-83; ALVES, José Carlos Moreira. Da alienação fiduciária em garantia. 3. ed. Rio de Janeiro: Forense, 1987, p. 2.

${ }^{2}$ É frequentemente realçado o papel das instituições financeiras enquanto intermediadoras do crédito, captando a poupança popular (atuando como devedoras) e a empregando na concessão de crédito (atuando como credoras). Cf. MOLLE, Giacomo. Manuale di diritto bancário. 2. ed. Milão: A. Giuffrè, 1977, p. 3 e 102.

${ }^{3} \mathrm{O}$ risco de crédito é assim definido pelo Banco Central do Brasil: "[...] define-se o risco de crédito como a possibilidade de ocorrência de perdas associadas ao não cumprimento pelo tomador ou contraparte de suas respectivas obrigações financeiras nos termos pactuados, à desvalorização de contrato de crédito decorrente da deterioração na classificação de risco do tomador, à redução de ganhos ou remunerações, às vantagens concedidas na renegociação e aos custos de recuperação" (Resolução 3.721/2009).

${ }^{4}$ COVELLO, Sergio Carlos. Contratos bancários. 4. ed. rev. e atual. São Paulo: Leud, 2001, p. 277.

${ }^{5}$ SZTAJN, Raquel. Sistema financeiro. Rio de Janeiro: Elsevier, 2010, p. 67.
} 
de um risco ${ }^{6}$ e consistem em uma "via de privilégio", reforçando a posição do credor frente à possível precariedade do patrimônio geral do devedor, o qual, quando de uma execução, pode estar definitivamente desfalcado ${ }^{7}$.

Logo, por estarem intrinsicamente conectadas ao crédito, fica claro o papel econômico central das garantias. ${ }^{8}$ Quanto mais segura a garantia, mais fácil, barata e abundante vai ser a concessão do crédito. Não à toa se vê uma incessante tentativa de encontrar a garantia ideal, que, ao mesmo tempo, seja constituída de modo simples e funcione "de forma rápida, eficaz e pouco onerosa".

Alves, nessa linha, ressalta que "para facilitar a obtenção do crédito, é indispensável garantir, da maneira mais eficiente possível, o credor, sem, em contrapartida, onerar o devedor a ponto de que fique, por causa da garantia, impedido de pagar o que deve, ou de utilizar, de imediato, daquilo que adquiriu a crédito" ${ }^{10}$.

A colocação é decorrência da situação em que se encontrava o sistema de garantias brasileiro após a primeira metade do século XX, com as principais garantias reais, a hipoteca e o penhor, já não mais satisfazendo adequadamente os interesses da sociedade, sendo consideradas "formas obsoletas"

\footnotetext{
${ }^{6}$ SILVA, Fábio Rocha Pinto e. Garantias das obrigações: uma análise sistemática do direito das garantias e uma proposta abrangente para sua reforma. São Paulo: Editora IASP, 2017, p. 57.

${ }^{7}$ VASCONCELOS, L. Miguel Pestana de. Direito das garantias. Coimbra: Almedina, 2011, p. 43-44. É o que também explica Noronha: "o patrimônio do devedor é a primeira garantia com que contam os credores, para a hipótese de haver inadimplemento; diz-se mesmo que esse patrimônio é a garantia comum dos credores, ou garantia geral das obrigações. É garantia que se traduz na sujeição à execução de todos os bens que constituem o patrimônio do devedor, ressalvados aqueles que são impenhoráveis; é ela que está subjacente a preceitos como os arts. 391 e 942, caput, do Código Civil (LGL120021400) e 591 do CPC (LGL1197315). Muitas vezes, porém, essa garantia é precária, seja porque o devedor tem patrimônio reduzido, seja porque tem muitas dívidas; é para estes casos que os interessados têm a possibilidade de providenciar outras garantias, conhecidas como garantias especiais, as quais podem ser pessoais (como a fiança e o aval) ou reais (como o penhor e a hipoteca)" (NORONHA, Fernando. A alienação fiduciária em garantia e o leasing financeiro como supergarantias das obrigações. Revista dos tribunais, São Paulo, v. 845, p. 37-49, mar. 2006).

${ }^{8}$ VASCONCELOS, L. Miguel Pestana de, op. cit., p. 50.

${ }^{9}$ Ibid., p. 51. Nessa linha, Silva é forte na lição de que a garantia ideal teria as seguintes qualidades: "(i) de constituição simples e pouco onerosa, para não aumentar o custo do crédito; (ii) adequada à dívida garantida nem em excesso, nem insuficiente -, a fim de evitar o abuso de garantias que desperdiça o crédito do devedor; (iii) eficaz, ou seja, conferir ao credor a certeza de que será pago, na hipótese de o devedor inadimplir a obrigação garantida; e (iv) de execução simples, a fim de evitar demoras e custos inúteis. De maneira concisa, podemos dizer que a garantia deve ser de constituição simples, adequada, material e processualmente eficaz" (SILVA, Fábio Rocha Pinto e. Garantias Imobiliárias em Contratos Empresariais: Hipoteca e Alienação Fiduciária. São Paulo: Almedina, 2014, p. 41).

${ }^{10}$ ALVES, José Carlos Moreira. Da alienação fiduciária em garantia. 3. ed. Rio de Janeiro: Forense, 1987, p. 2.

${ }^{11}$ WALD, Arnoldo. Da alienação fiduciária. Revista dos Tribunais, São Paulo, v. 400, ano 58, fev. 1969, p. 27.
} 
Três eram os maiores problemas das garantias reais tradicionais: (i) a questão da posse do bem, que no caso do penhor, mesmo com a superação da necessidade de entrega do bem móvel ao credor em algumas hipóteses, o devedor continuava obrigado a exercê-la sob o controle do credor $^{12}$; (ii) a questão da exclusividade sobre a garantia, pois além de a hipoteca e o penhor poderem ser constituídos sucessivas vezes sobre o mesmo objeto (artigos 1.456 e 1.476 da Lei ${ }^{\circ}$ 10.406/02 - Código Civil), ambos estavam sujeitos à insolvência do devedor e concorriam segundo a ordem de preferência legal, a qual, por sua vez, desprestigiava tais créditos em face dos trabalhistas, fiscais e de institutos e caixas de aposentadoria e pensão ${ }^{13}$; e (iii) a questão da crise judiciária que atingiu os países desenvolvidos e em desenvolvimento com o acúmulo exagerado de ações de execução infindáveis, que ressaltavam o fracasso na excussão dos direitos reais de garantia até então disponíveis ${ }^{14}$.

Estava clara a necessidade da criação de uma garantia mais "enérgica"15, que assegurasse, de uma só vez, a manutenção das atividades pelo devedor e a satisfação da obrigação $^{16}$, por meio de uma rápida recuperação do crédito na ocasião do inadimplemento, auxiliando, assim, a manter a estabilidade das fontes de captação e, consequentemente, os fluxos financeiros necessários para a concessão de novos empréstimos ${ }^{17}$.

Foi a oportunidade para que, em 1964, quando da implementação de medidas econômicas visando a fomentar a disponibilização de recursos para o desenvolvimento do comércio e do setor industrial, com a reforma bancária e o surgimento do mercado de capitais, institucionalizados pelas Leis $n^{\circ} 4.595 / 64$ e $4.728 / 65^{18}$, se criasse uma nova garantia

12 GOMES, Orlando. Alienação Fiduciária. 4. ed. São Paulo: Revista dos Tribunais, 1975, p. 186. Wald acrescenta nesse ponto que "as fraudes repetidas e generalizadas esvaziaram completamente o penhor mercantil como técnica de garantia de créditos” (WALD, Arnoldo. Da alienação fiduciária. Revista dos Tribunais, São Paulo, v. 400, ano 58, fev. 1969, p. 25).

${ }^{13}$ Cf.: LIMA, Otto de Sousa. Negócio fiduciário. São Paulo: Revista dos Tribunais, 1962, p. 134-135; CHALHUB, Melhim Namem; ASSUMPÇÃO, Márcio Calil de. Cessão fiduciária de direitos creditórios: aspectos da sua natureza jurídica e seu tratamento no concurso de credores. RTDC: Revista Trimestral de Direito Civil. Rio de Janeiro, v.10, n.38, abr./jun. 2009, p. 84.

${ }^{14}$ LOBO, Jorge. Cessão Fiduciária em garantia de recebíveis performados e a performar. In: ANDRIGHI, Fátima Nancy; BENETI, Sidnei; ABRÃO, Carlos Henrique. 10 anos de vigência da lei de recuperação e falência: (Lei n. 11.101/2005): retrospectiva geral contemplando a Lei $n^{\circ}$ 13.043/2014 e a Lei Complementar no 147/2014. São Paulo: Saraiva, 2015, p. 71.

${ }^{15}$ BUZAID, Alfredo. Ensaio sobre a Alienação Fiduciária em Garantia. Revista dos Tribunais, v. 401, ano 58, São Paulo, mar. 1969, p. 10.

${ }^{16}$ OLIVA, Milena Donato. Do negócio fiduciário à fidúcia, São Paulo: Atlas, 2014, p. 107-108.

${ }^{17}$ CHALHUB, Melhim Namem. Alienação fiduciária: Negócio fiduciário. 5. ed. rev., atual. e ampl. Rio de Janeiro: Forense, 2017, p. 6.

18 Cf.: AMARAL NETO, Francisco dos Santos. A alienação fiduciária em garantia no direito brasileiro. Revista de Direito civil, imobiliário, agrário e empresarial, São Paulo, v. 22, ano 6, out./dez. 1982, p. 36; e 
calcada na transferência da propriedade de um bem para o credor, de modo a afastar a "fragilidade estrutural da garantia constituída sobre bem alheio"19.

Assim, ficaria neutralizado o risco de excussão do bem por qualquer outro credor, especialmente com relação à insolvência do devedor ${ }^{20}$, e facilitada a realização da garantia, com a possibilidade de venda do bem pelo próprio credor, sem a necessidade do acionamento da máquina judiciária. ${ }^{21}$

A solução foi, portanto, passar pelo instituto que, segundo Rodotà, conta com a tutela jurídica mais forte em nossa sociedade: a propriedade. ${ }^{22}$ Até por isso, sendo a nova garantia muito mais poderosa que as garantias reais tradicionais, Noronha a chamou de supergarantia $^{23}$, enquanto Penteado foi ainda mais contundente, colocando-a como uma hipergarantia ${ }^{24}$.

Logo, a alienação fiduciária e a cessão fiduciária, nomes dos contratos que representam essas garantias baseadas na transferência da propriedade (propriedade fiduciária, como se verá), que serão chamadas para fins didáticos de garantias fiduciárias, se tornaram os contratos de garantia preferidos das instituições financeiras ${ }^{25}$, tendo permitido a expansão do crédito para consumo, especialmente nos setores de automóveis e eletrodomésticos ${ }^{26}$.

CANUTO, Elza Maria Alves. Alienação fiduciária de bem móvel: responsabilidade do avalista. Belo Horizonte: Del Rey, 2003, p. 97.

${ }^{19}$ RESTIFFE NETO, Paulo; RESTIFFE, Paulo Sérgio. Garantia fiduciária: direito e ações: manual teórico e prático com jurisprudência. 3. ed. rev., atual. e ampl. São Paulo: Revista dos Tribunais, 2000, p. 22.

${ }^{20}$ OLIVA, Milena Donato. Do negócio fiduciário à fidúcia. São Paulo: Atlas, 2014, p. 108.

${ }^{21}$ CHALHUB, Melhim Namem; ASSUMPÇÃO, Márcio Calil de. Cessão fiduciária de direitos creditórios: aspectos da sua natureza jurídica e seu tratamento no concurso de credores. RTDC: Revista Trimestral de Direito Civil. Rio de Janeiro, v. 10, n. 38, abr./jun. 2009, p. 91.

${ }^{22}$ RODOTÀ, Stefano. Il terribile diritto: studi sulla proprietà privata. 2. ed. Bolonha: Società editrice il Mulino, 1990, p. 17 e 19.

${ }^{23}$ NORONHA, Fernando. A alienação fiduciária em garantia e o leasing financeiro como supergarantias das obrigações. Revista dos Tribunais, São Paulo, v. 845, mar. 2006, p. 37-49.

${ }^{24}$ PENTEADO, Luciano de Camargo. Direito das coisas. São Paulo: Revista dos Tribunais, 2008, p. 431.

${ }^{25}$ NORONHA, op. cit., p. 37-49. A própria venda com reserva de domínio foi preterida pelas garantias fiduciárias, mesmo tendo em seu cerne igualmente a propriedade como forma de garantia do vendedor quanto ao adimplemento da dívida (FABIAN, Christoph. Fidúcia: negócios fiduciários e relações externas. Porto Alegre: Sergio Antonio Fabris Ed., 2007, p. 80-81).

${ }^{26}$ WALD, Arnoldo. Da alienação fiduciária. Revista dos Tribunais, São Paulo, v. 400, ano 58, fev. 1969, p. 25. Apesar do entusiasmo apresentado por Wald no referido texto, um contraponto deve ser apresentado. Possuindo uma garantia mais adequada à proteção do crédito, aqueles que emprestam devem ter consciência de que é necessária uma contrapartida, consubstanciada na redução dos juros praticados. De nada adianta um mecanismo muito mais efetivo de diminuição de risco se os mutuantes continuarão a não fazer a análise detalhada e real do risco de crédito dos tomadores (cf., nesse sentido, o detalhado estudo de Palhares, Cinara. 
Devido ao grande sucesso da nova garantia, que inicialmente não foi criada para a utilização geral, mas sim como uma exigência do mercado financeiro ${ }^{27}$, pouco a pouco ela foi se expandido para outros setores da economia até chegar numa aplicação mais generalizada do instituto, a ponto de ser o foco do sistema de garantias brasileiro nos dias atuais.

Ocorre que, ante uma sociedade que ansiava por uma solução imediata, a garantia que se calca na transferência da propriedade não foi estudada e inserida no sistema jurídico como deveria, de forma planejada e organizada. Pelo contrário, foi inserida de forma fragmentada e com diversas remodelações por meio de leis esparsas, na medida em que setores de mercado específicos, cada um ao seu tempo, se mostravam carentes.

Falta uma garantia mais segura para o mercado de capitais? Permite-se a garantia fiduciária de coisa móvel no setor (Lei $n^{\circ}$ 4.728/65). A construção civil precisa de fomento? Habilita-se a cessão fiduciária de direitos creditórios nessa seara (Lei $\mathrm{n}^{\mathrm{o}}$ 4.864/65). O mercado está com dúvidas sobre a aplicação da alienação fiduciária? Cria-se norma para regulamentar melhor a garantia (Decreto-Lei no 911/65). O mercado imobiliário precisa de incentivo? Possibilita-se a garantia fiduciária de coisa imóvel e a cessão fiduciária de direitos $\left(\right.$ Lei $n^{\circ}$ 9.514/97). Todos os setores anseiam por esse tipo de garantia? Cria-se a garantia fiduciária de coisa infungível de ampla utilização (Código Civil). O mercado de capitais precisa de outras garantias fiduciárias? Abre-se a possibilidade de utilização da cessão fiduciária de direitos (Lei no 10.931/04). A locação imobiliária está desestimulada? Permitese a garantia fiduciária de quotas de fundos de investimentos (Lei $\left.\mathrm{n}^{\mathrm{o}} 11.196 / 05\right)$.

Isso quando essas garantias não são concomitantemente disciplinadas em outras leis que tratam de um bem específico (independentemente do setor), como no caso das ações (Lei $\left.n^{\circ} 6.404 / 76\right)$ e das aeronaves (Lei no 7.565/86).

Ou seja, "esses regimes coexistem no ordenamento e incidem, ora simultaneamente, ora alternativamente, de acordo com as características subjetivas e objetivas do caso concreto" 28 .

Distribuição dos riscos nos contratos de crédito ao consumidor. Tese (Doutorado em Direito Civil). Faculdade de Direito da Universidade de São Paulo. São Paulo, 2014, p. 193-194 e 216).

${ }^{27}$ BUZAID, Alfredo. Ensaio sobre a Alienação Fiduciária em Garantia. Revista dos Tribunais, São Paulo, v. 401, ano 58, São Paulo, mar. 1969, p. 19.

28 TEPEDINO, Gustavo; BARBOZA, Heloisa Helena; MORAES, Maria Celina Bodin de. Código Civil interpretado conforme a Constituição da República, v. III. Rio de Janeiro: Renovar, 2011, p. 747. 
Quando da criação dessas leis, a preocupação primordial não foi a formação de um sistema único e coeso, mas apenas a aplicação em setores específicos. Contudo, essa falta de uma normatividade central, com a capilarização em microssistemas, faz com que qualquer característica básica das garantias fiduciárias se torne um verdadeiro embate jurídico. É como se já fossem conhecidas inúmeras "espécies” de garantias fiduciárias, mas o "gênero" em si ainda fosse uma categoria nebulosa.

A falta de sistematização das garantias que se baseiam na transmissão da propriedade fiduciária, com múltiplas normas promulgadas sem o menor cuidado com a coerência sistêmica, é de amplo conhecimento no meio jurídico, especialmente em função dos problemas daí decorrentes, como incoerência, contradição, incompreensão e insegurança. ${ }^{29}$

Nesse sentido, em termos concretos, a título de exemplo, além do antigo e já superado embate entre o Superior Tribunal de Justiça e o Supremo Tribunal Federal sobre o cabimento da prisão civil nessas garantias ${ }^{30}$, pode-se citar: a discussão sobre a submissão do credor fiduciário aos efeitos da recuperação judicial ${ }^{31}$; as discussões sobre as consequências do registro, surgindo novos questionamentos sobre sua aplicação geral ${ }^{32}$; o silêncio do Código Civil com relação à necessidade de consolidação da propriedade e notificação sobre a mora do devedor para a excussão da garantia ${ }^{33}$; a aplicabilidade geral da vedação ao pacto comissório $^{34}$; a possibilidade de o credor ficar com o bem dado em garantia em definitivo ${ }^{35}$ etc.

Isso sem contar o próprio questionamento que gira em torno da efetiva

\footnotetext{
${ }^{29}$ Veja-se, nesse sentido: OLIVA, Milena Donato; RENTERÍA, Pablo. Fidúcia: a importância da incorporação dos efeitos do trust no direito brasileiro. Revista Trimestral de Direito Civil, Rio de Janeiro, v. 48, out./dez. 2011, p. 56; SILVA, Fábio Rocha Pinto e. Garantias das obrigações: uma análise sistemática do direito das garantias e uma proposta abrangente para sua reforma. São Paulo: Editora IASP, 2017, p. 533-534; GUEDES, Gisela Sampaio da Cruz. TERRA, Aline de Miranda Valverde. Alienação fiduciária em garantia de bens imóveis: possíveis soluções para as deficiências e insuficiências da disciplina legal. In: GUEDES, Gisela Sampaio da Cruz; MORAES, Maria Celina Bodin de; MEIRELES, Rose Melo (coord.). Direito das Garantias. São Paulo: Saraiva, 2017, p. 220; MARTINS, Raphael Manhães. A propriedade fiduciária no direito brasileiro: uma proposta para a construção do modelo dogmático. Revista jurídica empresarial, n. 14, ano 3 , mai./jun. 2010, p. 146-149.

${ }^{30}$ Superado pela Súmula Vinculante $\mathrm{n}^{\circ} 25$ do Supremo Tribunal Federal, publicada em 2009, que ressaltou ser

"ilícita a prisão civil de depositário infiel, qualquer que seja a modalidade do depósito". Cf. Capítulo 3.3.4.2.

${ }^{31}$ Cf. Capítulo 3.3.1.1.

${ }^{32}$ Cf. Capítulo 3.2.2.

${ }^{33}$ Cf. Capítulo 3.4.1.

${ }^{34}$ Cf. Capítulo 3.4.2.2.

${ }^{35}$ Cf. Capítulo 3.4.2.4.
} 
transmissão da propriedade nas garantias fiduciárias e do impacto que a dita propriedade fiduciária gera no sistema jurídico brasileiro. ${ }^{36}$

\section{As garantias fiduciárias constituem mecanismo complexo e possuem} peculiaridades que merecem tratamento aprofundado. Não só lidam com uma propriedade com características muito diferentes de tudo que se estuda em relação a esse direito (limitada ao extremo, com distribuição incomum das obrigações e envolvendo também direitos pessoais), como também trazem um regime jurídico híbrido, envolvendo mútuo, resolubilidade, depósito, posse e a possibilidade de excussão extrajudicial. ${ }^{37}$ Daí a imprescindibilidade de uma sistematização, apta a diminuir a insegurança jurídica existente, neutralizando os inúmeros problemas por ela causados ${ }^{38}$, $\operatorname{como}$ as externalidades que gera no mercado ${ }^{39}$

Assim, é possível dizer que seria de muita utilidade a normatização expressa de uma teoria geral das garantias fiduciárias. ${ }^{40}$ Todavia, enquanto a estrutura geral não é dada, ${ }^{41}$

\footnotetext{
${ }^{36}$ Cf. Capítulo 4.

${ }^{37}$ Nessa linha, Carvalho afirma ser a alienação fiduciária um "instituto híbrido", pois compreende "Mútuo + propriedade resolúvel + alienação que não é venda + fidúcia + depositário com posse direta + adquirente com posse indireta" (CARVALHO, Milton Paulo de. Desconsideração do depósito em caso de prisão do alienante fiduciário. Revista Jurídica, n. 298, ano 50, ago. 2002, nota 22, p. 30).

${ }^{38}$ Como explica Wald: “A primeira causa da insegurança jurídica é certamente o relativo caos legislativo no qual vivemos, caracterizando-se tanto pelo excesso de leis, como pela falta de coerência do sistema e, algumas vezes, até pela falta de racionalidade de alguns dos textos legais. [...] Ora, a insegurança jurídica não se coaduna nem com o Estado de Direito, nem com o desenvolvimento nacional. Ao contrário, a incerteza quanto ao direito vigente representa uma incontestável causa do chamado 'custo Brasil' ou do 'risco Brasil', que onera o país e, consequientemente, pesa sobre todos os brasileiros e, em particular, cria uma taxa de juros incompatível com o progresso da nossa economia" (WALD, Arnoldo. A patologia do direito bancário: causas e soluções - uma primeira visão panorâmica. Revista de Direito Bancário e do Mercado de Capitais, São Paulo, v. 7, jan./mar. 2000, p. 36-52).

${ }^{39}$ Externalidade é um termo muito utilizado por economistas para tratar de custos ou benefícios nascidos de atividade e não suportados por seu exercente, mas sim por terceiros, dentre os quais se inclui a própria sociedade (SZTAJN, Rachel. Externalidades e custos de transação: a redistribuição de direitos no novo Código Civil. Revista de Direito Mercantil, no 133, ano XLIII, jan./mar. 2004, p. 7).

${ }^{40}$ Em Projeto de Lei apresentado em 1998 (PL nº 4.809/98), e ao final, não aprovado, o Deputado José Chaves, por ele responsável, em sua justificação, ressaltou que "não há dúvida de que essas figuras já regulamentadas no direito positivo brasileiro, com a ampliação e o aperfeiçoamento introduzidos pela mais recente lei, a de $\mathrm{n}^{\circ}$ 9.514/97, são instrumentos de extraordinária utilidade no funcionamento do mercado de capitais e no desenvolvimento dos negócios em geral. No entanto, neles observam-se algumas lacunas, deficiências ou inexatidões que podem gerar controvérsias ou insegurança jurídica”. Esses problemas poderiam se resolver por meio de uma "estrutura sistematizada que contempla as regras gerais concernentes à propriedade fiduciária e à segregação patrimonial, com o que se tornariam nítidos os direitos e deveres das partes, preenchendo-se as lacunas deixadas pela legislação vigente e estabelecendo rigorosos instrumentos de proteção dos investidores $[\ldots]^{\prime \prime}$.

${ }^{41}$ E não há perspectiva de que, na forma que se encontram hoje, as garantias fiduciárias efetivamente sejam sistematizadas pelo Legislador. Atualmente estão em trâmite no Poder Legislativo apenas propostas de incorporação dos efeitos do trust dos países de Common Law por meio de projetos de código comercial (PL n ${ }^{\circ}$ 487/13, em trâmite perante o Senado e aqui considerado em sua redação atualizada pelo Parecer $\mathrm{n}^{\circ} 1 \mathrm{de}^{\mathrm{C}}$ 11.12.2018, e PL n ${ }^{\circ}$ 1.572/11, em trâmite na Câmara dos Deputados e aqui considerado em sua redação dada
} 
ela pode muito bem ser encontrada, na tentativa de reforçar a segurança jurídica que o instituto procurou dar ao sistema de crédito brasileiro.

O presente estudo é, então, para analisar a legislação brasileira de forma sistemática, traçando um diálogo entre as diferentes fontes normativas, os entendimentos doutrinários e a jurisprudência, e buscando traços comuns entre todas as espécies de garantias fiduciárias a fim de delimitar uma teoria geral, aplicável a todas elas indistintamente. Nessa linha, o viés do estudo será mais analítico do que prospectivo, sem que se deixe de apresentar, sempre que necessário, o devido olhar crítico.

Importante ressaltar, ademais, que o objeto de estudo será exclusivamente a garantia baseada na transmissão da propriedade fiduciária e não a propriedade fiduciária por si só. Esta última está presente no ordenamento jurídico brasileiro com outras funções, como a de administração ${ }^{42}$, que não está compreendida no escopo do estudo.

Além disso, tendo como base a busca de uma estrutura geral, todo o cuidado foi tomado para não se adentrar em discussões específicas de cada garantia fiduciária que não impactem no estudo geral. As garantias fiduciárias possuem campo fértil para discussão em cada detalhe que as compõem, de modo que, sem o devido foco, o objeto central ficaria indevidamente diluído.

É em razão dessas especificidades de cada espécie que há uma abundância de estudos que tratam das garantias fiduciárias. Contudo, a esmagadora maioria das obras é voltada para uma ou outra espécie, sem tratar detidamente daquilo que seria aplicável a todas elas. Isso sem contar que já se passaram mais de 50 anos da criação da primeira garantia fiduciária no Brasil, sendo que, desde 1965, foram produzidas leis e mais leis alterando e complementando o regime jurídico das garantias fiduciárias, tendo a literatura jurídica se ocupado de abordar a constante mudança dos temas polêmicos ao longo de todo esse tempo.

Ainda, tratamento compreensivo teve que ser dado à produção jurisprudencial.

pelo substitutivo de 4.6.2018), que, assim como em outras tentativas pretéritas ( $\mathrm{PL} \mathrm{n}^{\circ} 3.362 / 57, \mathrm{PL} \mathrm{n}^{\circ} 3.264 / 65$ e $\left.P L n^{\circ} 4.809 / 98\right)$, apresentam pontos tangenciais às garantias fiduciárias, mas não uma sistematização destas garantias. Tanto que os artigos 476, $\S 1^{\circ}$, do PL n ${ }^{\circ} 487 / 13$ (cf.: “Art. 476. [...] $\S 1^{\circ}$. O contrato fiduciário pode ter o propósito de constituição de garantia, aplicando-se, no que couber, o disposto nos arts. 1.361 e seguintes do Código Civil [...]”) e o 353, $1^{\circ}$, do PL n ${ }^{\circ} 1.572 / 11$ (cf.: “Art. 353. [...] § $1^{\circ} \mathrm{O}$ contrato fiduciário pode ter o propósito de constituição de garantia, caso em que se submete às disposições legais aplicáveis à alienação fiduciária em garantia e, apenas na omissão destas, às disposições do presente Capítulo") são claros ao enunciar que para a função de garantia do contrato ali estabelecido se aplicarão as leis já existentes.

${ }^{42}$ Cf. Capítulo 3.3.1.2.2. 
Em um país com dimensões continentais, com um imenso número de decisões sendo proferidas diariamente tratando de um tema tão controverso como esse, é mais do que esperada a existência de decisões opostas a uma teorização geral em todos os seus aspectos. Dessa forma, foram considerados especialmente os entendimentos jurisprudenciais de maior abrangência (proferidos pelo Superior Tribunal de Justiça e pelo Supremo Tribunal Federal) ou aqueles de ocorrência reiterada em tribunais brasileiros, aptos a ensejar uma verdadeira discussão jurídica.

Dito isso, passa-se à estrutura do presente estudo. Primeiro serão abordados os institutos históricos que serviram de substrato para a criação das garantias fiduciárias brasileiras (Capítulo 1). Em seguida, analisar-se-á a evolução legislativa dessas garantias e a disposição dessas normas legais na atualidade (Capítulo 2), para então ser extraída uma teoria geral com base na legislação do modo que está posta, objeto principal deste estudo, passando, para isso, pela constituição e o funcionamento dessas garantias, bem como pelas consequências do inadimplemento das dívidas garantidas e pelas críticas feitas à estrutura identificada (Capítulo 3). 


\section{CONCLUSÃO}

Apesar de inexistir uma disciplina geral clara aplicável às garantias fiduciárias, mesmo considerando as alterações da Lei $n^{\circ} 10.931 / 04$, é possível identificar no direito brasileiro uma teoria geral das garantias fiduciárias.

Em todos os casos, as garantias fiduciárias nada mais são do que uma forma de garantir uma dívida por meio da transmissão da propriedade de bem do fiduciante para o fiduciário, conferindo a este uma garantia mais segura e efetiva. Esse é o pilar primordial das garantias fiduciárias, por si só suficiente para dirimir muitas controvérsias desnecessariamente impostas a algumas espécies dessas garantias.

A transmissão da propriedade é essencial nessas garantias pois dela decorrem os dois principais objetivos buscados quando de sua criação, quais sejam, (i) a retirada do bem da propriedade do fiduciante de forma a dar para o fiduciário exclusividade em eventual utilização do bem para satisfação da dívida (segurança) e (ii) a obtenção de propriedade pelo fiduciário, facilitando a execução da garantia no caso de inadimplemento (efetividade). É em razão da transferência da propriedade que as garantias fiduciárias não se sujeitam a execuções ou a procedimentos de concurso de credores direcionados contra o patrimônio do fiduciante (segurança). É em razão da transferência da propriedade que o fiduciário poderá realizar a venda extrajudicial do bem em caso de inadimplemento (efetividade).

Portanto, para a obtenção de uma teoria geral das garantias fiduciárias essa estrutura basilar e os objetivos que ela busca atingir devem ser rigidamente observados, sob pena de serem dadas interpretações distintas a institutos com a mesma finalidade.

Ainda que a propriedade recebida pelo fiduciário de fato não seja propriedade plena, mas propriedade fiduciária, importante ressaltar que esta é sim modalidade de propriedade exclusiva. Ela não deve ser considerada um direito real de garantia, tampouco uma propriedade dividida com o fiduciante. A propriedade fiduciária é modalidade de propriedade criada pelo legislador especificamente para cumprir a função de garantia, sem que deixe de ser propriedade em sua essência, tanto que tem a elasticidade necessária para retomar a condição de propriedade plena.

Ao criar a propriedade destinada exclusivamente à garantia de uma dívida, o legislador, para que todos os poderes do fiduciário pudessem ser unicamente conferidos para 
o atingimento deste fim e para evitar abusos por parte dele, criou a propriedade fiduciária como resolúvel, limitada e desonerada.

Pela resolubilidade, o fiduciante retoma a propriedade do bem com o simples adimplemento da dívida, de pleno direito. O caminho contrário, por sua vez, não é tão imediato. Quando do inadimplemento, são impostas limitações na resolubilidade, de modo que o fiduciário não se torna de imediato o pleno proprietário do bem, tampouco é livre para passar a utilizá-lo. O escopo fiduciário modula as atribuições do proprietário e os efeitos da resolubilidade.

Por ser a propriedade do fiduciário voltada para a função de garantia, ela é limitadíssima, não sendo conferidas a ele, em momento algum, as faculdades de usar e gozar. E mesmo o poder de disposição do bem só passa a existir quando do inadimplemento da dívida pelo fiduciante, mediante regras próprias que não a mera não ocorrência da condição resolutiva. Enquanto não ocorrido o evento de inadimplemento, o fiduciário está vedado de dispor do bem, não obstante seja ele de sua propriedade. Nesse período o bem é inalienável por força de lei, daí porque ser igualmente impenhorável por credores do fiduciário. Sendo inalienável e impenhorável, o concurso de credores igualmente não afeta o bem.

$\mathrm{Na}$ realidade, considerando esse direcionamento do bem unicamente para o cumprimento de uma finalidade, e, portanto, não tendo o fiduciário nenhum poder além do necessário para a consecução de tal escopo e não estando o bem sujeito às dívidas gerais do fiduciário, a propriedade fiduciária deve ser tida como patrimônio de afetação, de titularidade do fiduciário.

Além disso, a propriedade fiduciária também é desonerada, uma vez que, sendo a transmissão da propriedade um acessório, exclusivamente para garantir uma dívida, não pode ela gerar ônus que, ao invés de assegurar o cumprimento da obrigação, apenas a agrave. Logo, no âmbito de uma teoria geral é necessário lembrar que o fiduciário não deve ser responsabilizado por obrigações propter rem, nem por danos causados pelo bem, assim como não tem obrigações financeiras de conservação do bem e não corre os riscos da perda deste. Na propriedade fiduciária todos esses ônus são alocados na pessoa do fiduciante, que sequer se exime da dívida em caso de deterioração, perda ou perecimento do bem.

Essa é a peculiar propriedade fiduciária prevista pelo legislador com função de garantia, aplicável a todas as garantias fiduciárias, sem distinção, e que depende de dois 
elementos para ser constituída: a celebração de um contrato (título) e a efetivação do registro desse contrato na repartição competente (modo).

O contrato deverá ser escrito, para que dele constem disposições obrigatórias sobre as características da dívida e a identificação do bem submetido à função de garantia, sob pena da própria impossibilidade de constituição da garantia. Além disso, o contrato poderá ter como objeto bem imóvel, bem móvel fungível, bem móvel infungível e direitos patrimoniais, podendo ser celebrado por todos os sujeitos capazes, apesar de nem todos os sujeitos poderem celebrar tais contratos em todas as ocasiões.

O registro, em seu turno, vai além da produção de efeitos contra terceiros. Ele é essencial para que a transferência da propriedade se efetive. Ou seja, para que se tenha uma interpretação coesa das garantias fiduciárias, elementar considerar que o registro será o modo de aquisição da propriedade em todas elas.

Ademais, tal como nos direitos reais de garantia, as garantias fiduciárias são indivisíveis e a dívida que elas garantem será considerada antecipadamente vencida, por força da lei, quando o fiduciante se tornar insolvente ou inadimplente de uma parcela da dívida e quando o bem dado em garantia se deteriorar, depreciar ou perecer e não for a garantia reforçada ou substituída, ou se o bem for desapropriado.

Por fim, em casos de não pagamento da dívida garantida, em que pese a diversidade de procedimentos, as garantias fiduciárias têm em comum a consolidação da propriedade em nome do fiduciário, desde que atendido o pré-requisito geral de ser o fiduciante notificado sobre a mora.

Essa consolidação não permitirá, em regra, que o fiduciante fique definitivamente com o bem, pois ele está obrigado a tentar vendê-lo para satisfação da dívida, entregando eventual quantia que sobejar ao fiduciante ou, não alcançando a venda o valor da dívida, cobrando do fiduciante o saldo remanescente.

No entanto, apesar da necessidade de venda e a impossibilidade do fiduciário estipular no contrato de constituição das garantias fiduciárias cláusula que o permita ficar com o bem como forma de quitação da dívida (pacto comissório), existem algumas formas do fiduciário ficar com o bem definitivamente, quais sejam: (i) quando da celebração do contrato, pactuar a possibilidade do fiduciário ficar com o bem mediante avaliação idônea e desde que devolvido ao fiduciante a parte do valor avaliado que ultrapasse o montante da 
dívida (pacto marciano); e, (ii) quando do vencimento da dívida sem o devido adimplemento, acordar com o fiduciante a dação do direito dele ao bem como forma de quitação ou adjudicar o bem em processo judicial, também após avaliação idônea.

Essa é a estrutura típica encontrada para o gênero das garantias fiduciárias. Com ela é possível dirimir grande parte das controvérsias que assolam a utilização dessas garantias, sendo sua aplicação essencial para propiciar a segurança jurídica tão cara ao direito das obrigações. 


\section{REFERÊNCIAS}

ADAMEK, Marcelo Vieira von. Do endosso-mandato. Revista de direito mercantil, industrial, econômico e financeiro, São Paulo, v. 142, ano 45, p. 108-140, abr.jun. 2006.

ALVES, José Carlos Moreira. Da alienação fiduciária em garantia. 3. ed. Rio de Janeiro: Forense, 1987.

Da fidúcia romana à alienação fiduciária em garantia no direito brasileiro. In: CAHALI, Yussef Said. Contratos nominados: doutrina e jurisprudência. São Paulo: Saraiva, 1995.

ALVES, Vilson Rodrigues. Alienação fiduciária em garantia: as ações de busca e apreensão e depósito - a impossibilidade de prisão civil do devedor. Campinas: Milennium, 1998.

AMARAL NETO, Francisco dos Santos. A alienação fiduciária em garantia no direito brasileiro. In: Revista de Direito Civil, imobiliário, agrário e empresarial, São Paulo, v. 22, ano 6, p. 36-49, out./dez. 1982.

AMENDOLARA, Cesar. Alienação Fiduciária Como Instrumento de Fomento à Concessão de Crédito. In: WAISBERG, Ivo; FONTES, Marcos Rolim Fernandes (coord.). Contratos Bancários. São Paulo: Quartier Latin, 2006.

ASCARELli, Tullio. Problemas das Sociedades Anônimas e direito comparado. 2. ed. São Paulo: Saraiva, 1969.

AZEVEDO, Álvaro Villaça. Contratos inominados ou atípicos e negócio fiduciário. 3. ed. Belém: Cejup, 1988.

2000.

. Prisão Civil por Dívida. 2. ed. rev., atual. e ampl. São Paulo: Revista dos Tribunais,

Alienação fiduciária de bem imóvel. Revista Magister de Direito Civil e Processual Civil, Porto Alegre, n. 1, ano 1, p. 41-49, jul./ago. 2004.

AZEVEDO, Antonio Junqueira de. Negócio Fiduciário. Frustração da fidúcia pela alienação indevida do bem transmitido. Oponibilidade ao terceiro adquirente dos efeitos da fidúcia germânica e de procuração em causa própria outorgada ao fiduciante. In: Novos estudos e pareceres de direito privado. São Paulo: Saraiva, 2009.

BENACCHIO, Marcelo. Comentários ao Código Civil: direito privado contemporâneo. In: NANNI, Giovanni Ettore (coord.). São Paulo: Saraiva Educação, 2018.

BETTI, Emilio. Teoria geral do negócio jurídico. Campinas: Servanda Editora, 2008.

BEVILAQUA, Clovis. Código Civil dos Estados Unidos do Brasil comentado, v. III. 5. ed. Rio de Janeiro: Francisco Alves, 1938.

BONFANTE, Pietro. Istituzioni di diritto romano. 9. ed. rev. e atual. Milão: Vallardi, 1932.

BUZAID, Alfredo. Ensaio sobre a Alienação Fiduciária em Garantia. Revista dos 
Tribunais, São Paulo, v. 401, ano 58, p. 11-29, mar. 1969.

CAMPINHO, Sérgio. Sociedades anônimas. 2. ed. São Paulo: Saraiva, 2017.

CANUTO, Elza Maria Alves. Alienação fiduciária de bem móvel: responsabilidade do avalista. Belo Horizonte: Del Rey, 2003.

CARIOTA-FERRARA, Luigi. I negozi fiduciari. Pádua: Cedam, 1933.

. Negozio Giuridico Nel Diritto Privato Italiano. Napoli: Morano, 1949.

CARVALHO, Milton Paulo de. Desconsideração do depósito em caso de prisão do alienante fiduciário. Revista Jurídica, Blumenau, n. 298, ano 50, p. 21-46, ago. 2002.

CARVAlHOSA, Modesto; KUYVEN, Fernando. Tratado de Direito Empresarial, v. 3. São Paulo: Revista dos Tribunais, 2016.

CASTRO, João Mendes de Oliveira; et al. Temas polêmicos de alienação fiduciária em garantia: a responsabilidade do credor fiduciário por obrigações propter rem. In: Revista de Direito Bancário e do Mercado de Capitais, São Paulo, v. 74, p. 175-202, out./dez. 2016.

CHALHUB, Melhim Namem. Alienação fiduciária: Negócio fiduciário. 5. ed. rev., atual. e ampl. Rio de Janeiro: Forense, 2017.

Alienação fiduciária de bens imóveis. 20 anos de vigência da Lei 9.514/1997. In:

Revista de Direito Imobiliário, São Paulo, v. 84, p. 495-531, jan./jun. 2018.

; ASSUMPÇÃO, Márcio Calil de. Cessão fiduciária de direitos creditórios: aspectos da sua natureza jurídica e seu tratamento no concurso de credores. RTDC: Revista Trimestral de Direito Civil, Rio de Janeiro, v. 10, n. 38, p. 81-110, abr./jun. 2009.

COELHO, Fábio Ulhoa. A cessão fiduciária de títulos de crédito ou direitos creditórios e a recuperação judicial do devedor cedente. Revista Magister de Direito Empresarial, Concorrencial e do Consumidor, Porto Alegre, n. 34, ano 6, p. 21-34, jul./ago. 2010.

COMPARATO, Fábio Konder. Financiamento a consumidor com alienação fiduciária Alienação fiduciária - Aval. Revista dos Tribunais, São Paulo, v. 514, ano 67, p. 49-55, ago. 1978.

CORDEIRO, António Menezes. Tratado de Direito Civil Português, v. 1: parte geral, t. 1. Coimbra: Almedina, 1999.

2000 .

Tratado de Direito Civil Português, v. 1: parte geral, t. 2. Coimbra: Almedina,

COVELLO, Sergio Carlos. Contratos bancários. 4. ed. rev. e atual. São Paulo: Leud, 2001.

COVIELLO, Nicola. Manuale di Diritto Civile Italiano, v. 1. 4. ed. Milão: Società Editrice Libraria, 1929.

CUEVA, Ricardo Villas Bôas. A trava bancária na jurisprudência do STJ. In: ANDRIGHI, Fátima Nancy, BENETI, Sidnei, ABRÃO, Carlos Henrique. 10 anos de vigência da lei de 
recuperação e falência (Lei n. 11.101/2005): retrospectiva geral contemplando a Lei $\mathrm{n}$. 13.043/2014 e a Lei Complementar n. 147/2014. São Paulo: Saraiva, 2015.

DANTZGER, Afranio Carlos Camargo. Cessão fiduciária dos direitos do fiduciante Financiamento bancário e consórcio. In: Revista de Direito Bancário e do Mercado de Capitais, São Paulo, v. 56, ano 15, p. 77-89, abr./jun. 2012.

DELGADO, Mário Luiz. A purgação da mora nos contratos de alienação fiduciária de bem imóvel. Uma questão de direito intertemporal. Revista de Direito Imobiliário, São Paulo, v. 84, p. 441-461, jan./jun. 2018.

DEL NERO, João Alberto Schutzer. Considerações sobre a eficácia do registro, efetuado em registro público material e territorialmente competente, de negócios jurídicos de obrigação e de certos negócios jurídicos de disposição. Revista de direito mercantil, industrial, econômico e financeiro, São Paulo, v. 166/167, ano 53, p. 219-271, ago. 2013 a jul. 2014.

DIAZ-CAÑABATE, Joaquín Garriguez. Negocios fiduciários em derecho mercantil. Madri: Civitas, 1976.

DINIZ, Maria Helena. Dicionário Jurídico, v. 4. São Paulo: Saraiva, 1998.

EIZIRIK, Nelson. Lei das S/A comentada, v. 1. São Paulo: Quartier Latin, 2011.

FABIAN, Christoph. Fidúcia: negócios fiduciários e relações externas. Porto Alegre: Sergio Antônio Fabris, 2007.

FACHIN, Luiz Edson. Comentários ao Código Civil: parte especial: direito das coisas, v. 15 (arts. 1.277 a 1.368). In: AZEVEDO, Antônio Junqueira de (coord.). São Paulo: Saraiva, 2003.

FERNANDES, Jean Carlos. Cessão fiduciária dos títulos de crédito. Rio de Janeiro: Lumen Juris, 2009.

FERRARA, Francesco. A simulação dos negócios jurídicos. São Paulo: Saraiva, 1939.

FERREIRA, Waldemar. O "trust" anglo-americano e o "fideicomiso" latino-americano. Revista da Faculdade de Direito, São Paulo, v. 51, p. 182-202, 1956.

FIUZA, Ricardo (coord.). Novo código civil comentado. 4. ed. São Paulo: Saraiva, 2005.

FRAGA, Affonso. Direitos reaes de garantia: penhor, antichrese e hypotheca. São Paulo: Saraiva \& Comp., 1933.

FRANCESCHELLI, Remo. Il “Trust” nel diritto inglese. Pádua: Cedam, 1935.

La garanzia reale dei crediti nel diritto romano clássico e nel diritto inglese (fiducia cum creditore e mortgage. In: Studi in memoria di Aldo Albertoni, v. III. Pádua: Cedam, 1935.

FOERSTER, Gerd. O "trust” do Direito Anglo-Americano e os negócios fiduciários no Brasil: perspectiva de direito comparado (considerações sobre o acolhimento do "trust" pelo direito brasileiro). Porto Alegre: Sergio Antonio Fabris Ed., 2013. 
FULGÊNCIO, Tito. Direito real de hipoteca, v. I. Atualização de José de Aguiar Dias. Rio de Janeiro: Forense, 1960.

GODOY, Luciano de Souza; SERAFIM, Tatiana Flores Gaspar; MARTINIANO, Marcela Machado. O processo de recuperação judicial testa a eficácia do patrimônio de afetação. Revista de Direito Recuperacional e Empresa, São Paulo, v. 6, out./dez. 2017.

GOMES, Orlando. Contrato de Fidúcia ("trust"). In: Revista Forense, Rio de Janeiro, v. 211, ano 62, p. 11-20, jul./set. 1965.

Alienação Fiduciária. 4. ed. São Paulo: Revista dos Tribunais, 1975.

Introdução ao Direito Civil. 14. ed. Rio de Janeiro: Forense, 1999.

Direitos reais. Atualização de Humberto Theodoro Júnior. 18. ed. Rio de Janeiro: Forense: 2002.

GONÇALVES, Aderbal da Cunha. Da propriedade resolúvel: sua projeção na alienação fiduciária em garantia. São Paulo: Revista dos Tribunais, 1979.

GONÇALVES, Carlos Roberto. Direito Civil Brasileiro, v. 5. 4. ed. São Paulo: Saraiva, 2009.

GRAU, Eros Roberto. Negócio jurídico inexistente - Alienação fiduciária em garantia: existência, validade e eficácia do negócio jurídico. In: Revista de direito civil, imobiliário, agrário e empresarial, São Paulo, v. 40, ano 11, p. 160-170, abr./jun. 1987.

GUEDES, Gisela Sampaio da Cruz. TERRA, Aline de Miranda Valverde. Alienação fiduciária em garantia de bens imóveis: possíveis soluções para as deficiências e insuficiências da disciplina legal. In: GUEDES, Gisela Sampaio da Cruz; MORAES, Maria Celina Bodin de; MEIRELES, Rose Melo Vencelau (Coords.). Direito das Garantias. São Paulo: Saraiva, 2017.

; _ Pacto comissório vs. Pacto Marciano: estruturas semelhantes com repercussões diversas. In: GUEDES, Gisela Sampaio da Cruz; MORAES, Maria Celina Bodin de; MEIRELES, Rose Melo Vencelau (Coords.). Direito das Garantias. São Paulo: Saraiva, 2017.

HILDEBRAND, Lucas Fajardo Nunes. Patrimônio, patrimônio separado ou especial, patrimônio autônomo. In: AZEVEDO, Erasmo Valladão; FRANÇA, Novaes (coord.). Direito Societário Contemporâneo I. São Paulo: Quartier Latin, 2009.

JACQUELIN, René. De la fiducie. Paris: A. Giard, Libraire-Éditeur, 1891.

KOJRANSKI, Nelson. Pacto comissório e a alienação fiduciária. In: NASCIMBENI, Asdrubal Franco; MARCACINI, Augusto Tavares Rosa; BERTASI, Maria Odete Duque (coord.). Contratos empresariais interpretados pelos tribunais. São Paulo: Quartier Latin, 2015.

LIMA, Otto de Sousa. Negócio fiduciário. São Paulo: Revista dos Tribunais, 1962.

LOBO, Jorge. Cessão Fiduciária em garantia de recebíveis performados e a performar. In: 
ANDRIGHI, Fátima Nancy; BENETI, Sidnei; ABRÃO, Carlos Henrique (Coords.). 10 anos de vigência da lei de recuperação e falência (Lei n. 11.101/2005): retrospectiva geral contemplando a Lei n. 13.043/2014 e a Lei Complementar n. 147/2014. São Paulo: Saraiva, 2015 .

LONGO, Carlo. Corso di diritto romano: la fiducia. Milão: A. Giuffrè, 1933.

LOPES, Miguel Maria de Serpa. Curso de direito civil, v. 6: Direito das coisas. Atualização de José Serpa Santa Maria. 4. ed. Rio de Janeiro: Freitas Bastos, 1996.

LOUREIRO, Francisco Eduardo. Código Civil comentado: doutrina e jurisprudência, 8. ed. In: PELUSO, Cezar (Coord.). Barueri: Manole, 2014.

MARINO, Francisco Paulo de Crescenzo. Notas sobre o negócio jurídico fiduciário. Revista Trimestral de Direito Civil, Rio de Janeiro, v. 20, ano 5, p. 35-63, out./dez. 2004.

Contratos coligados no direito brasileiro. São Paulo: Saraiva, 2009.

MARKY, Thomas. Curso elementar de direito romano. 8. ed. São Paulo: Saraiva, 1995.

MARTINS-COSTA, Judith. Os negócios fiduciários - considerações sobre a possibilidade de acolhimento do "trust" no direito brasileiro. Revista dos Tribunais, São Paulo, v. 657, ano 79, p. 3-50, jul. 1990.

MARTINS, Fran. Comentários à Lei das Sociedades Anônimas. 4. ed., rev. e atual. Rio de Janeiro: Forense, 2010.

MARTINS, Raphael Manhães. A propriedade fiduciária no direito brasileiro: uma proposta para a construção do modelo dogmático. Revista jurídica empresarial, n. 14, ano 3, p. 145 162, mai./jun. 2010.

MARRONE, Matteo. Istituzioni di diritto romano. 3. ed. Palermo: Palumbo, 2006.

MARTORELL, Mariano Navarro. La propriedad fiduciária. Barcelona: Bosch, 1950.

MEIRA, Sílvio Augusto de Bastos. Instituições de direito romano. 2. ed. São Paulo: Max Limonad, 1962.

MIRANDA, Custódio da Piedade Ubaldino. Negócio jurídico indireto e negócios fiduciários. Revista de Direito Civil, Imobiliário, Agrário e Empresarial, v. 29, ano 8, p. 81-94, jul./set. 1984.

MIRANDA, Francisco Cavalcanti Pontes de. Tratado de Direito Privado, t. 3, 3. ed. Rio de Janeiro: Borsoi, 1970.

Tratado de Direito Privado, t. 11. Atualização de Luiz Edson Fachin. São Paulo: Revista dos Tribunais, 2012.

Tratado de Direito Privado, t. 21. Atualização de Nelson Nery Jr. e Luciano de Camargo Penteado. São Paulo: Revista dos Tribunais, 2012.

Tratado de Direito Privado, t. 23. Atualização de Nelson Nery Jr. e Rosa Maria 
de Andrade Nery. São Paulo: Revista dos Tribunais, 2012.

MESSINA, Giuseppe. Scritti Giuridici, v. 1. Milão: A. Giuffrè, 1948.

MOLLE, Giacomo. Manuale di diritto bancário. 2. ed. Milão: A. Giuffrè, 1977.

MONTEIRO, Washington de Barros. Curso de direito civil, v. 3: Direito das coisas. 35. ed. rev. e atual. São Paulo: Saraiva, 1999.

NASSER, Paulo Magalhães; SILVA, Candice Buckley Bittencourt. Anotações sobre a propriedade fiduciária e a alienação fiduciária em garantia. In: VENOSA, Sílvio de Salvo; GAGLIARDI, Rafael Villar; NASSER, Paulo Magalhães (Coords.). 10 anos do Código Civil: desafios e perspectivas. São Paulo: Atlas, 2012.

NOGUEIRA, André Carvalho. Propriedade fiduciária em garantia: o sistema dicotômico da propriedade no Brasil. Revista de Direito Bancário e do Mercado de Capitais, São Paulo, n. 39, ano 11, p. 56-78, jan./mar. 2008.

NORONHA, Fernando. A alienação fiduciária em garantia e o leasing financeiro como supergarantias das obrigações. Revista dos Tribunais, São Paulo, v. 845, p. 37-49, mar. 2006.

OLIVA, Milena Donato.; RENTERÍA, Pablo. Fidúcia: a importância da incorporação dos efeitos do trust no direito brasileiro. Revista Trimestral de Direito Civil, Rio de Janeiro, v. 48, p. 27-61, out./dez. 2011.

OLIVA, Milena Donato. Do negócio fiduciário à fidúcia. São Paulo: Atlas, 2014.

. O contrato fiduciário previsto no Projeto de Lei do Senado 487/2013: titularidade fiduciária e separação patrimonial. In: COELHO, Fábio Ulhoa; LIMA, Tiago Astor Rocha; NUNES, Marcelo Guedes (Coords.). Novas reflexões sobre o projeto de código comercial. São Paulo: Saraiva, 2015.

OLIVEIRA, Gleydson Kleber Lopes de. Comentários ao Código Civil brasileiro, v. 12: da propriedade, da superfície e das servidões. In: ALVIM, Arruda; ALVIM, Thereza (Coord.). Rio de Janeiro: Forense, 2004.

PALHARES, Cinara. Distribuição dos riscos nos contratos de crédito ao consumidor. Tese (Doutorado em Direito Civil) - Faculdade de Direito, Universidade de São Paulo, São Paulo, 2014.

PENTEADO, Luciano de Camargo. Direito das coisas. São Paulo: RT, 2008.

PEREIRA, Caio Mário da Silva. Instituições de direito civil, v. 4. 21. ed. Rio de Janeiro: Forense, 2013.

PEREIRA, Lafayette Rodrigues. Direito das coisas, adaptação ao Código Civil por José Bonifácio de Andrada e Silva. 6. ed. Rio de Janeiro: Freitas Bastos, 1956.

PETTIT, Philip H. Equity and the law of trusts. 10. ed. Oxford: University Press, 2006.

POTTER, Harold. Potter's historical introduction to English law and its instittutions. 
Atualização de Albert Kenneth Roland Kiralfy. 4. ed. Londres: Sweet \& Maxwell, 1958.

RESTIFFE, Paulo Sérgio. Garantias tradicionais no novo Código Civil. Revista dos Tribunais, São Paulo, v. 821, p. 731 et seq, mar. 2004.

RESTIFFE NETO, Paulo; RESTIFFE, Paulo Sérgio. Garantia fiduciária: direito e ações: manual teórico e prático com jurisprudência. 3. ed. rev., atual. e ampl. São Paulo: Revista dos Tribunais, 2000.

RIZZARDO, Arnaldo. Responsabilidade civil. Rio de Janeiro: Forense, 2005.

ROBERT, Bruno. Dividendo mínimo obrigatório nas S.A.: apuração, declaração e pagamento. São Paulo: Quartier Latin, 2011.

RODOTÀ, Stefano. Il terribile diritto: studi sulla proprietà privata. 2. ed. Bolonha: Società editrice il Mulino, 1990.

RODRIGUES, Silvio. Direito civil: Direito das coisas, v. 5. 28. ed. rev. e atual. de acordo com o novo Código Civil. São Paulo: Saraiva, 2003.

SACRAMONE, Marcelo Barbosa; PIVA, Fernanda Neves. Cessão fiduciária de créditos na recuperação judicial: Requisitos e limites à luz da jurisprudência. Revista de Direito Bancário e do Mercado de Capitais, São Paulo, v. 72, p. 133-155, abr./jun. 2016.

SANTOS, Joaquim Antonio de Vizeu Penalva. O negócio fiduciário no direito brasileiro. In: SANTOS, Theophilo de Azevedo (Coord.). Novos estudos de direito comercial em homenagem a Celso Barbi Filho. Rio de Janeiro: Forense, 2003.

SANTOS, José Beleza dos. A simulação em direito civil. 2. ed. São Paulo: Lejus, 1999.

SCALZILLI, João Pedro; SPINELLI, Luis Felipe; TELLECHEA, Rodrigo. Recuperação de empresas e falência. São Paulo: Almedina, 2016.

SILVA, De Plácido e. Vocabulário Jurídico. 18. ed. Rio de Janeiro: Forense, 2001.

SILVA, Fábio Rocha Pinto e. Garantias Imobiliárias em Contratos Empresariais: Hipoteca e Alienação Fiduciária. São Paulo: Almedina, 2014.

. Garantias das obrigações: uma análise sistemática do direito das garantias e uma

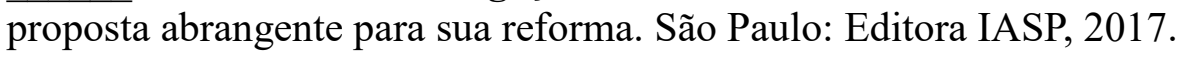

SILVA, Luiz Augusto Beck da. Alienação fiduciária em garantia. 3. ed. Rio de Janeiro: Forense, 1998.

SZTAJN, Rachel. Externalidades e custos de transação: a redistribuição de direitos no novo Código Civil. Revista de Direito Mercantil, São Paulo, n. 133, ano XLIII, jan./mar. 2004.

. Sistema Financeiro. Rio de Janeiro: Elsevier, 2010.

STEPHEN, Sir James Fitzjames. Commentaries on the laws of England, v. II: law of property. Atualização de Edward Jenks. 18. ed. Londres: Butterworth, 1925.

STURZENEGGER, Luiz Carlos; CAVALCANTI, Henrique Leite. A situação do 
proprietário fiduciário de direitos creditórios em garantia, originados de contratos de cessão fiduciária, nos casos de submissão do devedor a regime de quebra. Revista de Direito Bancário e do Mercado de Capitais, São Paulo, v. 63, ano 17, p. 43-70, jan./mar. 2014.

TEIXEIRA, Egberto Lacerda; GUERREIRO, José Alexandre Tavares. Das sociedades anônimas no direito brasileiro. São Paulo: J. Bushatsky, 1979.

TEPEDINO, Gustavo. A incorporação dos direitos fundamentais pelo ordenamento brasileiro: sua eficácia nas relações jurídicas privadas. Revista da AJURIS, n. 100, ano 32, p. 153-167 dez. 2005.

.; BARBOZA, Heloisa Helena; MORAES, Maria Celina Bodin de. Código Civil interpretado conforme a Constituição da República, v. III. Rio de Janeiro: Renovar, 2011.

TERRA, Marcelo. Alienação fiduciária de imóvel em garantia. Porto Alegre: Sergio Antonio Fabris, 1998.

VASCONCELOS, L. Miguel Pestana de. A Cessão de Créditos em Garantia e a Insolvência - Em Particular da Posição do Cessionário na Insolvência do Cedente. Coimbra: Coimbra Editora, 2007.

Direito das garantias. Coimbra: Almedina, 2011.

VASCONCELOS, Pedro Pais de. Contratos Atípicos. Tese (Doutorado em Direito) da Universidade de Coimbra. Coimbra: Almedina, 1995.

VENOSA, Sílvio de Salvo. Código civil comentado: direito das coisas, posse, direitos reais, propriedade, artigos 1.196 a 1.368, v. XII. In: AZEVEDO, Álvaro Villaça (Coord.). São Paulo: Atlas, 2003.

Direito civil: reais. 18. ed. São Paulo: Atlas, 2018.

VIANA, Marco Aurelio da Silva. Comentários ao Novo Código Civil, v. xvi: dos direitos reais. In: TEIXEIRA, Sálvio de Figueiredo (Coord.). Rio de Janeiro: Forense, 2003.

WALD, Arnoldo. Da alienação fiduciária. Revista dos Tribunais, São Paulo, v. 400, ano 58, p. 25-30, fev. 1969.

Novos instrumentos para o direito imobiliário: fundos, alienação fiduciária e "leasing". Revista dos tribunais, São Paulo, v. 432, ano 60, p. 249-253 out. 1971.

Algumas considerações a respeito da utilização do "trust"" no direito brasileiro. Revista de Direito Mercantil, Industrial, Econômico e Financeiro, São Paulo, n. 99, ano 34, p. 105-120, jul./set. 1995.

A patologia do direito bancário: causas e soluções - uma primeira visão panorâmica. Revista de Direito Bancário e do Mercado de Capitais, São Paulo, v. 7, p. 36-52, jan./mar. 2000 .

Direito das coisas. Atualização de Álvaro Villaça Azevedo e Véra Fradera. 11. ed. São Paulo: Saraiva, 2002. 